\title{
The Democratic Values of the Student Movement in Kosovo 1997/1999 and Their Echoes in Western Diplomacy
}

\author{
Lulzim NIKA ${ }^{1}$ \\ Correspondence: Lulzim NIKA. \\ Received: March 19, 2018 Accepted: April 16, 2018 Online Published: May 15, 2018 \\ doi:10.5539/res.v10n2p167 URL: https://doi.org/10.5539/res.v10n2p167
}

\begin{abstract}
After the fall of east orientated political system and coming of the pluralistic system in the Yugoslav federation, the nationalisms that claimed to dominate Yugoslavia, such as Serbian, Croatian and Slovenian nationalism came to the surface, which also led to the overthrow of Yugoslavia. Following the abolition of Kosovo's limited autonomy of 1974, in March 1989, the Milosevic Serb regime during the 1990s imposed violent measures in all Kosovo institutions by removing Albanian workers from their jobs. Thus, Kosovo, Albanians were expelled collectively from the education process in the Albanian language, and left school and university facilities. Efforts to reach an agreement between Albanians and Serbian representatives for education during 1992 were unsuccessful. In these difficult contexts, the parallel education system of Kosovo Albanians was organized. In these difficult circumstances, students and Albanian students continued learning outside school facilities. After ignoring the Kosovo problem in the peace agreement reached in Dayton for Bosnia, the dissatisfaction with the peace policy led by Dr. Ibrahim Rugova grew all over Kosovo. In these circumstances, professors and students with vision began to talk about the organization of peaceful protests against the Serbian regime. After a long process, a new student movement took place at the University of Prishtina, which marks the beginning of the great protest on 1 October 1997. In this paper, we analyse the attitudes of international diplomacy with a special emphasis on the West in relation to this movement following the 1 October 1997 peace protests in Kosovo.
\end{abstract}

Keywords: Student Movement in Kosovo, Protest of October 1, Western Diplomacy for Kosovo

\section{Introduction}

The history of the student movement in Kosovo starts with the 1968 demonstrations. It has been two decades since the return of the dignity and hope for Kosovo's freedom began with the undeniable sacrifice of professors and students of the University of Prishtina who organized the peaceful protest for returning to school facilities. The student protests of 1997 are the continuation of the protests of 1968 and 1981, which marked the decisive turning point that changed the course of political developments in Kosovo, making great international echoes.

Although the year 1968 was recognized as a year of student movement in Europe, where the most popular universities of France, Germany and England were involved in the wave of student's ruction of the "new left", yet they did not reflect the Albanian student movement. That was because the European student movement had a social character; it was social movement and aimed for a better social order, while the student movement of Kosovo had a national character, a character of resistance against a centurie-old wild bondage. The 1968 demonstrations were of great importance to the Albanian people because they were a priority for raising awareness among the Albanian people that international diplomacy understood that the Albanian people were being crushed from Serbia.

At this time in the reports of the US Embassy in Belgrade, Kosovo's economic and political situation was described as very severe and differentiated from other Yugoslav's1 regions. In the 1968 Special Report of the United States, the American Information Service, the demonstrations of the 1968 presents as a revolt of denial of the political and economic rights of the Albanian minority living in Kosovo. "Kosovo and Metohija are the poorest in the region and the most excluded from the Yugoslav's political system, where economic and cultural pressures have created significant differences of up to six or seven in per capita income between Kosovo and Slovenia, both of which belong to the territory of the Jugoslav Federation" 2with other regions at the Document taken from the archives of President London XHonson in Austin TX.

\footnotetext{
${ }^{1} 1$ London B. Johnson Presidential Library, Folder Title Albania,Volume1,Form of Document Memo Doc, Number 1 1/2 from Dawis to Rostow, Collection National Security File, Box Number, 163.

${ }^{2}$ Lyndon B. Johnson Presidential Library, Folder Title, Yugoslavia, Form of Document CIA, Document Number 106 Document Description is Central Intelligence Agency. Yugoslavia-The Fall of Rankovic, Box Number: 232.
} 
It is important that in the chronology of the history of student demonstrations we also dwell in the Demonstrates of 1981. The student movement in Kosovo continued its unresolved resistance for their demands that always were denied by the Serbian conqueror. In the midst of these efforts, the massive spring demonstrations of '81 (March-April) are considered as the main events in Yugoslavia after Tito's death. Initially, the student revolt at the university environments, they quickly escalated into nationwide protests throughout Kosovo. The 1981 spring events brought to the surface unexplained problems in Yugoslavia - for many, they constituted the prologue of the destruction of the socialist experiment that tried vainly to overcome ethnic antagonisms. With the election of US President Ronald Reagan, an aggressive policy towards the East and the socialist and communist political system was established. In the foreign policy of the United States, all social and class, political turmoil in the north-eastern world was in the function of American politics that was determined on the destruction of the political system of East. In addition, all the developments and moves that fell into conflict with the political system of the East camp were in favour and support of the US to prove that the political system of East that was in conflict with respecting human rights and jeopardized peace and global security had to be changed. In this perspective should also be seen the 1981 student demonstrations that were organized by Albanian nationalist groups that had leftist ideologies with the purpose of establishing the political status of Kosovo in the Yugoslav Federation. All political developments in the east that were in conflict with the political system were in function of justifying US policy for necessary changes of the political system that jeopardized peace and security in the world3. These can be testified by the documents of the Presidential Library of the President Ronald Reagan.

After the imposition of violent measures during the 1990s and the removal of Albanian professors and students from school facilities followed attempts to mediate by Europeans, Americans, and the failure of these talks. The protest of professors and students for returning to their school facilities that was held in 1992, the Serbian regime used violence to disperse the peaceful protest ${ }^{4}$. The reactions of international institutions were in support of the protests and their legitimate demands. In the letter that President Bush informed the French president, describes as a very serious situation for human rights, especially in the field of education and culture for Albanians in Kosovo. In the letter that President Fransua Mitrean's returned, besides expressing concerns about the information from Kosovo, he emphasizes that it is unbending for Europe to deny the right to the education system for a collective community. -Taken from the archive of the President GJ.H Bush-.

The Dayton Agreement completely changed the attitude of Kosovo Albanians. After this agreement, it noted that peaceful resistance was not supported by Western diplomacies, and that their serious engagement was only in places where violence detonated, such as Bosnia and Croatia. The dissatisfaction with the political parties in Kosovo was growing all over Kosovo, but the culmination was when an agreement signed between S. Milosevic and I. Rugove for returning to school facilities and the normalization of education did not implement.

\section{Student Protests October 1, 1997}

After the violent takeover of Kosovo's limited autonomy (the 1974 Constitution), the Serb conqueror in his education legislation designed injustice, institutionalizing educational and cultural genocide over Albanians. The Serbian invasion government in July 1990 decided to put violent measures in all Kosovo institutions by removing all Albanian workers from their jobs, including Kosovo's elementary and university education. At the end of the 1990 in Kosovo, Albanian pupils, students, and professors violently left their school facilities, denying them the most basic right to education. With these discriminating decisions of the Serb invaders, Albanians did not agree and organized protests to oppose these unfair decisions. For these Serbia's discriminatory actions had also reacted many international institutions condemning Serbian government's decisions to stop the education of two million Albanians in Kosovo. In October 1992, were the peaceful protests by students, professors and citizens to release school facilities where Serbian police exerted brutal violence against peaceful protesters ${ }^{5}$. In January of 1992, concerned about the closure of school facilities in Kosovo, the US embassy In Belgrade began a dialogue on the normalization of education in Kosovo. With the initiative of the Americans, a meeting was held between representatives of the Serb pair for education in Pristina and the Albanian delegation for the

\footnotetext{
${ }^{3}$ Ronald Regand Presidential Library, Director of Central Intelligence ID ,Decal 943054,40 Prospects for Post - Tito Yugoslavia National Intelligence Estimate.

4 Amnesty International,Report,1992, f,279, Yugoslavia (the Socialist Federal Republic of),Publications, London Wc1x8dj United Kingdom,1992.

${ }^{5}$ National Archives and Records Administration, George Bush Presidential Library Record ID 9209012,Doc Date: 07 Dec 92 From: Francois Mitterrand, Subject: Ltr From: Pres Mitterrand to Pres Bush, Action: Prepare Memo for Scowcroft Date:17 Dec 92 Staff officer: Wayne.
} 
normalization of education, but the meeting did not produce results, it did not succeed ${ }^{6}$. Later also with the mediation of Gert Arens, leader of the Contact Group of the Geneva Conference, held talks on Albanian education in Kosovo, but did not yield results ${ }^{7}$. However, the efforts of Albanian students and professors to return to school facilities never quenched. It was a constant demand, but until 1997 there would be no significant action to separate, but there were only statements and resolutions of various international institutions which supported the right of Albanians to education and return to the school buildings that were occupied, and opposed the difficult situation and discrimination created by Serbian forces. In October 1997, mass protests were organized by UP students and professors as well as thousands of non-violent citizens in Pristina. They wanted the right to go back to university. They simultaneously demonstrated against the pacifist politics of Rugova, who had done an educational agreement on the normalization of the lessons with Milosevic, which did not change anything in the education system of Albanians. The Serbian regime, with the exception of some sporadic actions before October 1, 1997, committed by the KLA, did not recognize and did not experience any other civil resistance. The Drenica area in the meantime had become one of the main bases of the KLA. Student protests of October 1, 1997 as a continuation of the student resistance of the 1968-1981 year.

The suppression of Kosovo's autonomy in 1989 by the Serbian regime created unfavourable circumstances in all areas of life in Kosovo, including the higher education system. The organization of the work of the University of Prishtina and its survival in the home-schools was a special and unprecedented event in the history of universities. "Even during this organization, the Serbian regime of Milosevic barely hindered the work of the University of Prishtina" ${ }^{8}$, which was the only institution of higher education in Kosovo.

During the new academic year, the violent leader, dominated by Serbo-Montenegrin cadres, increased the number of students to 923 students, mostly Serbian students brought from different parts of Serbia and Montenegro. On August 21, 1991, the Helsinki group in Vienna issued a statement stating that Albanian education in Kosovo no longer existed and that it had been destroyed by Serbia. ${ }^{9}$ In the reports of the US Embassy in Belgrade that they send to the US Department of State for the organization of demonstrations in October 1992, organized by Albanian teachers and professors for returning to their facilities, wrote: "The demonstrations were peaceful and according to the witnesses were approximately 50,000 participants who had requested to return to their school facilities, Serbian police forces violently intervened and scattered demonstrators in front of the square where they gathered to demonstrate, using tear gas and other violent means, the police had begun in all the ways of controlling and harassing the Albanian population, in general, the situation in Pristina remains tense, this is also said by the Yugoslav official news agency Tanjug... " ${ }^{10}$.In the description of the demonstrators by US diplomats it is shown that basic human rights in Kosovo were violated. Despite the attempts to return to the school facilities Albanian professors and students, the Serb conqueror denied them this elementary right. But, in the beginning of 1992, the aim is to find opportunities and forms for the Albanian school to begin to be active. ${ }^{11}$

On February 14, 1992, the University of Prishtina announced that on February 17, 1992, it would start teaching at the university level. On 17 February 1992 begins the academic year at home-faculties. On 10 June 1992, the UP Assembly decided that in the academic year 1992/93 7 thousand and 99 young students would enrol. On July 1, 1992, the new leadership of the UP was elected. Rector with a two-year mandate, "Professor Ejup Statovci" was elected, who became the symbol of intellectual invincibility in UP's protection". ${ }^{12}$

The University of Prishtina was the generator of Albanian patriotic movements in the areas of Yugoslavia, and especially the student youth was always at the forefront of protecting national interests. After the elections of ISUPU(The Independent Student Union of the Albanian Pristina University UPSUP) held on 4 February 1997, and the election of the leadership and the chairperson of ISUPU, Bujar Dugolli came to the dynamism of the student movement with fair requests

\footnotetext{
${ }^{6}$ National Archives and Records Administration, George Bush Presidential Library. Electronic Message - Yugoslavia January 1992 [OA/ID CFO1401].

${ }^{7}$ Kosovo's Center of Information, 13.10.1992, Prishtina.

${ }^{8} 3$ Council for the Protection of Human Rights and Freedoms in Pristina, Report of February and March 1992, Pristina. 8 Bush Presidential Library, Record ID 9209012,Doc Date: 07 Dec 92 From: Francois Mitterrand, Subject: Ltr From: Pres Mitterrand to Pres Bush, Action: Prepare Memo for Scowcroft Date:17 Dec 92 Staff officer.

${ }^{9}$ National Archives and Records Bush Presidential Library, Record ID 9209012 Keywords: Yugoslavia,Albania, Subject: Reply to Rep Zeliffre Situation in Kosovo.

${ }^{10}$ National Archives and Records Administration Georg H. W. Bush Presidential Library, National Security Council, Memorandum For: subject, Kosovo VMS Mail User Bleicken 13 - Oct - 1992.

${ }^{11}$ Bujar Dugolli, 1 Tetori i kthesës 1997-1999,Univerziteti i Prishtinës,2013, 25.

12 Newspaper “Bujku”, 2 July 1992, Prishtina, 1.
} 
for peaceful protests for the release of school facilities. The decision for peaceful protests found support both in the internal and international opinion, and especially in the professors and students of the UP, that for the entire Albanian society the brutality of the Serbian invader had become impatient. Thus, all the circumstances were created so that students make a historic decision to protest for their return to school facilities.

As noted above, student youth, on October 1, 1997, came to the forefront of a nonviolent movement, applying the active methods of a civil resistance, which echoed in the domestic and international public. Milosevic's regime, stamping violently the protest of October 1, 1997, and other protests, was subsequently discredited badly in the eyes of the international factor, who realized that the discrimination and systematic violation of human rights and freedoms of the Kosovo Albanian population had come to the critical point. Following these recent events before Kosovo's rescue resistance led by the Kosovo Liberation Army began, international diplomacy tried to give peace a chance to encourage students from the University of Prishtina to continue with the resistance and with peaceful protests and on the other hand, encouraging the process of interethnic dialogue to resolve the Kosovo issue. ${ }^{13}$

The idea for starting student demonstrations was born at the end of 1996 and early 1997 by frequent conversations and analyzes by the students, "Bujar Dugolli, Muhamet Mavraj, Driton Lajçi and Nazmi Muzlijaj." ${ }^{14}$ In January 1997, the students had written a petition of 550 signatures to President Ibrahim Rugova, but instead of getting answers, many of the students that had signed were arrested by Serbian police under various charges. ${ }^{15}$ However, these signatures had their own effect, as students were electrified by their views on and against the petition. Then no one knew that the students had links to the KCL and the KLA, which helped them with their own double challenge, both against Serbs and pacifist politics. ${ }^{16}$

In August 1997, students in Pristina started organizing protests, because Serbian authorities had not implemented the 1996 education agreement signed by Serbian's President Slobodan Milosevic and Kosovo's President Ibrahim Rugova with the mediation of the association "St. Egjidio" by the Vatican.

In September 1997, Ibrahim Rugova had tried to divide students and stop holding their protests, but students lost trust in political parties and when he asked in September to stop the demonstrations, the students did not listen to the words his. Ibrahim Rugova was even against peaceful demonstrations organized by the students of the University of Prishtina, reasoning with the famous slogan "we must be careful not to strain the situation without need, so as not to 'We give Serbia a chance for any massacre'.

At a meeting with students, Rugova had not backed them for holding protests and had begged their protests to postpone for an indefinite period. However, the students had rejected his request, saying that they were determined to hold the protest on October 1. Driton Lajci, vice president of UP's USD on BBC's journalistic questioning whether a protracted postponement of protests can be talked about, Driton Lajçi said, "We can listen to President Rugova only if there is a great excuse, any major reason for postponing the protests." The American diplomat Robert Gelbard had given students support, "peaceful protests are completely acceptable". ${ }^{17}$ Also, the Albanian Embassy in Belgrade, Artan Begolli and Florian Nova, the Democratic Party of Albania and its chairman Sali Berisha, hundreds of electronic support messages from Tirana, Skopje, European countries, Canada, USA etc., as well as many professors of UP, who encouraged students to endure.

During this period, the Student Movement had begun to reorganize and oppose the policy of waiting against the Serbian invaders. It, led by Mayor Bujar Dugolli, Muhamet Mavrajt, Driton Lajçi, Albin Kurti, etc., also found support from Professor and Rector Ejup Statovci, who with his experience and the spirit of an intellectual patriot led them on the right road of resistance and freedom. The people had already started thinking differently. On October 1, 1997, some 20,000 students managed successfully to face the Serbian police, who beat and arrested many of the students and their professors. There were similar demonstrations in other parts of Kosovo. The protests in 1997 continued on the schedule of the Organizing Council on October 29 and December 30, 1997, for students of resistance. ${ }^{18}$

Local press, "Koha Ditore", "Bujku", separately, Albanian Political Weekend "Zëri", etc., gave strong support to students protests, which awakened from the lethargy to the settlement centres, the Serbian invader, but also the political factor

\footnotetext{
13 Bujar Dugolli, 1 Tetori i kthesës, vep. e cit. 9.

14 Intervistë e Driton Lajçit, ish-udhëheqës i studentëve në vitin 1997, "Epoka e re”, 1 tetor 2005, .8.

15 Komunikatë e LPK-së, 1 tetor 1997, Prishtinë.

16 Tim Judah, Kosova, luftë dhe hakmarrje, vep. e cit. 172.

17 Newspaper "Bujku”, 1 September 1997, Prishtina, 1997.

18 Tim Juda, Kosova, luftë dhe hakmarrje, vep. e cit. 172.
} 
Albanian. ${ }^{19}$ To echo the demands of UP students, the editorial board of the "Zëri I Kosovës" newspaper made an agreement with the newsletter of the "New World" newspaper to come up with the same material.

On October 1, 1997, some 20,000 students of the University of Prishtina flooded the streets of the capital protesting the wild violence used by the Serbian government over the people of Kosovo.

Armed to the teeth, the students managed to withstand numerous beatings and arrests. October 1, 1997 remains a date marking the first step towards political movements, but also liberating. Against the brutality that Serbian forces used on peaceful protesters reacted all Western governments, condemning Serbian violence against peaceful protesters. "The United States strongly condemns the use of violence in Kosovo against peaceful protesters by Yugoslav and Serbian police", said in a statement by State Department spokesperson James Foley ${ }^{20}$. Foulli called on Serbian authorities to respect the rights of citizens for peaceful protests. On October 6, 1997, the US Special Envoy for the Balkans, Robert Gelbart at the US Embassy in Belgrade after meeting with Milosevic, hosted Kosovo's political representatives and held a one-hour meeting with the Independent Union Student Delegation, showing determination to continue peaceful protests until the release of school and university facilities. In a press release after meeting with political representatives and independent Union of students of the University of Prishtina, he expressed the satisfaction for having a meeting with Albanian political representatives and expressed delight because of student behaviour in the recent demonstration in Pristina when they did not respond violently to violent police intervention. ${ }^{21}$ After the demonstration of October 1,1997 , organized by the student youth of those years, come the massive mobilization and expansion of the Kosovo Liberation Army, which included Albanians in all their areas, whose epilogue we all know.

Bujar Dugolli, the charismatic leader of UP students, later on in his memoirs will say about the demonstrations that after about 20 years of successful work of the University of Prishtina, 1989-1990 marked the beginning of unstoppable Serbian efforts for destroying higher education in Kosovo. With the advent of Slobodan Milosevic to Serbia, an ultranationalist figure of the Serbian politics, which prompted the Albanian national politics against Albanians, first among Kosovo Serbs, then in Serbia and beyond, the Albanian school in Kosovo, in particular The University of Prishtina took great strides that led to serious risk, with the size of the destruction of Albanian education. Serbian nationalist power was committed to changing and stopping the Albanian language in Kosovo.

The people disagreed with Serbian actions and mobilized themselves in defence not only of Kosovo's political, but also in the defence of Albanian education. In 1989, tens of hundreds of demonstrations and protests were organized, in which, were killed and injured. This situation continued during 1990 with the organization of demonstrations, protests, strikes, etc., where students, teachers, professors, workers and citizens of all categories were almost daily on the street to defend the Albanian school.

The state of the university came to deteriorate, alongside the situation throughout Kosovo. The University Centre was no longer the shelter of students and of the Albanian professors.

In the contemporary history of Kosovo, the year 1997 presents a stage in itself, it is characterized in the first place by the dynamism of the political and diplomatic life of the internal factor as well as the external factor for solution of the Kosovo's issue. During September 1997, Ibrahim Rugova had a visit to Germany and after returning to Kosovo, he had warned of "the German-American initiative to resolve the Kosovo issue that will begin in October 1997". ${ }^{22}$ German Foreign Minister Klaus Kinkel declared to "Rilindja" that with Rugova it was discussed mainly about intensifying high-level dialogue between Pristina and Belgrade as well as for the joint US-American initiative, which should begin in October, with a tour the joint Gilbert-Ishinger in Kosovo. Even though it was hoped that this diplomatic initiative of the two influential countries would not have an impact on the Kosovo problem or at least in the realization of the education agreement this did not happen and this initiative did not produce results and was used only as a reason not to protest on October 1st, 1997. The peaceful protests gave a turnaround to the events in Kosovo in general and in particular, the Kosovo issue began to impose on international diplomacy to turn all projectors out of the unresolved Kosovo problem.

Leaders, ideologists, and organizers of peaceful protests for returning to the occupied buildings by Serb invaders faced the brutal violence of Serbian police forced on peaceful demonstrators. The organizers of the 1 October peaceful protests, faced with the opposition of the DLK leadership (Democratic League of Kosovo), which also organized a group of students who held a meeting with the leader Ibrahim Rugova, supporting the idea that protests should be postponed at a

19 “Koha ditore”, 30.9.1997, Prishtinë; "Bujku”, 3.10.1997, Prishtinë; “Zëri”, 4.10.1997, Prishtinë.

20 National Archives Unatet State, William J. Clinton, Presidential Library, and Museum, Fund Kosovo FOIA2006-1186-F, 1997, Department State Brifing Kosovo,11,01.

21 Newspaper "Bujku”, 7 October 1997, Prishtina.

${ }^{22}$ Newspaper "Bujku”, 10 September 1997. 
time another and insisting on the division of students for daily political purposes.

This divisive approach had no effect on the student's youth who had the courage to stop the peaceful protests up to the most basic right to education in their university facilities.

The peaceful protests of 1 October 1997 played a very important and historic role in the dynamism of political developments in resolving the Kosovo's issue. The protesters' exit in an organized manner to realize the rights to education was a message to the international public that the student's youth had lost patience .Also the protest was a warning to the political parties in Kosovo how much dissatisfaction had been made and suggesting that the Albanian youth can not agree with the passivity in the political organization of the Albanians and the difficult state of Kosovo. After the announcements of the protests of the students of the University of Prishtina, pressures began as well as by some foreign diplomats and some local political circles. On September 28, 1997, following the warning of students for protests, the Ambassadors of Contact Group and the representative of Russia came for the first time in Pristina. The diplomats had held talks with Kosovo leader Ibrahim Rugova and were notified on the latest developments in Kosovo and for determining for "independence with an international oversight as a transitional stage". ${ }^{23}$ The American Office had sent an invitation to the Independent Student Union of UP. At the meeting with student representatives at the US Office in Pristina, there was a request for postponement of the protest and the risk and responsibility of students in escalating the violence in Kosovo, saying, "The international community is interested in a peaceful solution to the Kosovo's problem". ${ }^{24}$ At this meeting it is important to note that the most vocal for not holding the fair protest of the students of the University of Prishtina for returning to school facilities were the Russian and French ambassadors. ${ }^{25}$ They were stubborn in their attitudes that the announced protest on October 1, should not be kept because "because they will aggravate the already fragile situation in Kosovo". Students during the talks with ambassadors expressed their concern that the agreement did not include higher education in Kosovo and about the curricula and showed pessimism that Milosevic did not understand the language of dialogue, but that of enforcing the implementation of agreements that he himself signed them and did not respect them. Some of the ambassadors were fierce in the demand to attract students from peaceful protests and the right to release school facilities, by duly accountable students for destabilizing the situation and not becoming the cause of bloodshed in Kosovo. The student delegation showed determination in their attitudes and showed that they would not withdraw from the peace protest on October 1, 1997, the students told the ambassadors that we have nothing to lose and pray to observe the peaceful protests of students and citizens on October 1st. The elementary right guaranteed by many international conventions for the expression of free thought and peaceful protests was demanded by students to respect the Contact Group ambassadors. The US ambassador, Richard Miles, addressing the chairperson of ISUPU said: "Mr. Dugolli, we have not come here to pressure you not to keep the protests and not to express your thoughts with the dissatisfaction you have with the Belgrade government, but we suggest you to put them off for a while. ${ }^{26}$ "Contact Group Diplomats faced a rejection of students who began a new era of intolerance for the grave condition in Kosovo. Politics in Pristina had been very audible to foreign diplomats and had not been known for any action that was in conflict with diplomacy, especially the Western. Therefore, the student movement took the courage to oppose the sleep diplomacy of some of our friends that the Albanian people do not intend to disagree with and submit to the Serbian criminal conqueror. Ibrahim Rugova's objection and request for postponement also had the same justification to give a chance to a dialogue that for a year had failed to implement the education agreement signed on September 1, 1996 on the release of school facilities. Students showed determination and began not to listen to diplomats' suggestions for the postponement of peaceful protests, marking a new step for Prishtina's submissive politics as obedience to the international factor. That has never been rewarded for this move, for five years up to the warning for peaceful protest of students; they had not found time to listen to the difficulties experienced by the Albanian youth in Kosovo at the end of the 20th century, denying them the most basic right for education.

Peaceful protests by students and citizens of Kosovo begin to be supported after October 1 by diplomats from Western and American countries as well. This is evidenced by the meeting organized after the protests at the US Embassy in Belgrade and the reception given to the student delegation by the US envoy for the Balkans, Robert Gellbard, who "congratulated the students for the peaceful protest", supporting their demands as legitimate and promising that there will be greater

\footnotetext{
${ }^{23}$ Kosovo Information Center, Press Release, after President Ibrahim Rugova's meeting with the Contact Group ambassadors, 28 September 1997, Pristina.

24 Archive of the Independent Student Union of the University of Prishtina, Meeting with the Contact Group Ambassadors, September 28, 1997, at the American Office in Pristina. 1997.

25 Bujar Dugolli, 1st of October turning, University of Prishtina, Pristina, 2013, 140.

26 Archive of the Independent Student Union of the University of Prishtina, Meeting with the Contact Group representatives, Pristina, September 1997.
} 
diplomatic engagement in resolving these problems. ${ }^{27}$

1. Supporting the fair demands of students of the University of Prishtina for returning to school facilities, protesting peacefully and without violent behavior, by the representative of the US President for the Balkans, Robert Gellbard was a proof that without a resistance active it was difficult to change the difficult state of Kosovo. Peaceful and fair protests to release school facilities were of particular importance in engaging, powerful diplomatic factors to intervene in resolving the Kosovo's issue in diplomatic ways before escalating any open conflict between the efforts of Albanians for independence and Serbian invaders, who insisted on keeping Kosovo in a Serbian colony at the end of the XX century. Statements and some resolutions by international institutions that had been passed for violating human rights by the Serbian conqueror did not change the grave and tense situation in Kosovo that only went to an armed conflict.

2. The former US ambassador to Yugoslavia rightly recalled in his memoirs in the beginning of the conflict and efforts for independence of the Yugoslav republics, such as Slovenia and Croatia, in his memoirs of Serbian politics led by Slobodan Milosevic wrote, "Serbian nationalism under Milosevic became more and more aggressive." 28

The efforts of Serbian politics, failing to realize the education agreement that were its signatories, wanted to take time to open the case of Kosovo, its political and legal status.

It was the opinion of many analysts of the time that the education agreement and any agreement with Serbia will not matter if the final status of Kosovo is not resolved. For this, the students of the University of Prishtina were aware of it, and it was not by chance the change of goals from the massive student protests of students and citizens on October 1, where by slogans and requests was priority the release of educational facilities and the right for education.

With the public appearance of representatives of the Kosovo Liberation Army in the burial of Halit Geci, in the village of Llaushë / Drenica, there were hopes that freedom would come to Kosovo. Even if the diplomatic efforts at this time failed to bring about all sorts of plans Kosovo's status, from the special status of extended autonomy or as some Western diplomats called substantial autonomy that guarded Serbian sovereignty over Kosovo.

Student protests, adapting to circumstances created after the KLA public outreach, began to be in support of Drenica, which at this time had become a powerful warrior core of Kosovo's freedom. The student movement was of historical importance after a long time of empowering and installing the Serbian invader in Kosovo, showing hope for massaging all forms of opposition to the Serbian invader, chanting and supporting the Kosovo Liberation Army as well as in front of many joined students and political support for a just war for freedom.

\section{Resources and Literature}

\section{Archival Funds}

USNA United States National Archives

1. Lyndon B Johnson Presidential Library, Austin, Texas, USA. Folder Title Albania, Volumme 1, Form of Document Memo Docu, Number 1From Dawis to Rostow, Collection National Security File, Box Number, 163.

Folder Title, Yugoslavia, Form of Document CIA, Document Number 106 Document Description: Central Intelligence Agency, Yugoslavia-The Fall of Rankovic, Box Number, 232.

2. Ronald Regand Presidencial Library, Simi Valley,CA, USA. Dirctor of Central Intelligenc ID, Dec1 943054,40 rospects for Post- Tito Yugoslavia National Intelligence Estimate

3.George H.W. Bush Presidential Library, College Station, TX, USA.

4. Fond of Bush, Presidential Records Staff and Office Files, National Security Council Craig Chellis Files - Subject Files(41) CSCE [ Conference on Security and Cooperation in Europe] - Yugoslavia Crisis [OA/ ID CFO1441]

5. Blair Dominey Files - Subject Files Yugoslavia [OA/ID CF00232]

6. Jane Holl Files - Electronic Files Electronic Messages - Kosovo [1] [0A/ID CFO1566] Kosovo[2][OA/ID CFO1566] Kosovo [3] [OA/ID CFO1566] Kosovo [4] [OA /ID CFO1566] Electronic Messages - Kosovo [OA/ ID CF 01746] London Conference [1], [2], [3]. Jane Holl Files -Subject Files Balkans [OA/ ID CFO1747],

7. DCI Interagency Balkan Task Force [3] [OA/ID CFO174] Kosovo [OA]/ID CFO1747]

27 "Koha Ditore", 10 September 1997, Prishtina.

${ }^{28}$ Warren Zimmerman, Origins of a Catastrophe Yugoslavia and its Destroyers W.Z. American's Last Ambassador to Yugoslavia, With an updated Preface and Epilogue on Bosnia and Kosovo, Times Books, New York 1996, 13. 
8. Bill Clinton Presidential Library, Little Rock,AR, USA

9. Clinton Presidental Library Record ID: 9804443 to: Beegun Dana, Keywords: Kosovo Humanitarian Assistance, Subject: Letter from Interaction Kosovo, Conflict.

\section{AMFAA Archives of the Ministry of Foreign Affairs of Albania}

\section{Archival Funds}

1. Kosova's Fond, File No. 1148, Title of Material, Radiograms by our Embassy in Kosovo, on the Situation in Kosovo, 12-01-90-02-11-1990, Tirana.

2. Kosova's Fond, File No. 1583, B V11- 2 DH,Title of Material, For Germany's attitude toward Kosovo, year 1991,Tirana.

3. Kosova's Fond, File No. 1609, B V11/2, Title of Material, About the Situation in Kosovo 1991, Tirana.

\section{References}

(1990). Grup of authors, the truth about Kosovo and Albanians in Yugoslavia, Academy of Science of Albania's RPS \& Institute of History, Tirana.

(1997). Archive of the Independent Student Union of the University of Prishtina, Meeting with the Contact Group Ambassadors, September 28, at the American Office in Pristina.

Amnesty International Report. (1992). Yugoslavia (the Socialist Republic), Publications, London WC1X8DJ, United Kingdom.

Anna, Di L. (2006). The case for Kosova, Anthem Press, London \& New York.

Bajram, G. (2009). The Rambouillet Conference, AIKD, Prishtina.

Christopher, R. H. (2014). Outpost Life on the Frontlines of American Diplomacy, Simon \& Schuster, New York Edition Octomber, $f, 124-125$.

Henry, H., \& Perritt, Jr. (2008). Kosovo Liberation Army: Inside confession from a revolution, Prishtina.

Joschka, F. (2008).The red-green years, Koha, Prishtina.

Jusuf, B. (2012). Kosovo from the London Conference to the International Protectorate, "Faik Konica", Prishtinë.

Leonard, D. (2000). Albania and American diplomacy, Onufri, Tirana.

Misha, G. ( 2007). Ballkan's History, 1804-1999, Toena, Tirana.

Noel, M. Kosova, a short story, Koha \& Shtëpia e librit, Prishtina-Tirana.

Philip, E., \& Auerswald, D. (2000). The Kosovo Conflic. A Diplomatic History through Documents, Kluwer Law International Cambridge/The Hague, f., 18.

Zimmerman, W. (1996). Origins of a Catastrophe Yugoslavia and its Destroyers W.Z. American Last Ambassador to Yugoslavia, with an updated Preface and Epilogue on Bosnia and Kosovo, Times Books, New York.

\section{Copyrights}

Copyright for this article is retained by the author(s), with first publication rights granted to the journal.

This is an open-access article distributed under the terms and conditions of the Creative Commons Attribution license (http://creativecommons.org/licenses/by/4.0/). 